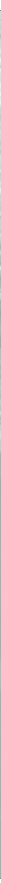

Bakgrunn: Selvskading er en hyppig årsak til døgninnleggelse i akutt psykisk helsevern til tross for at retningslinjer fraråder dette. Det er undersøkt lite om hva som er bedringsfremmende under slike opphold.

Hensikt: $\AA$ utforske hvordan kvinner med erfaring med selvskading opplever at bedringsprosessen kan fremmes under døgninnleggelse akutt psykisk helsevern.

Metode: Studien har et fenomenologisk-hermeneutisk design. Det er gjennomført intervjuer og e-postut- veksling med fem kvinner som har egenerfaring med temaet.

Funn: Bedringsprosessen var knyttet til 1) betydningen av felleskap, 2) betydningen av likeverd og 3) betydningen av å ta ansvar. Beskrivelsen «fordi det er mennesker der» utgjorde helhetsforståelsen av studien. Ønske om innleggelse opplevdes som en mestringsstrategi. Mulighet for tilbaketrekning ble beskrevet som viktig i bedringsprosessen. Akuttposten representerte samtidig en god treningsarena med et fysisk og sosialt miljø som kunne bidra til bedring. Tilgjengelig helsepersonell ble ansett som grunnmuren i bedring ved innleggelse og særegent ved akuttposten. Helsepersonell hadde betydning både for at pasienten følte seg verdsatt og for å bli utfordret til ansvarliggjøring.

Konklusjon: Avgjørende for at innleggelse fremmer bedring, er tilgjengelig helsepersonell som anerkjenner pasientens autonomi og medbestemmelse som et grunnlag for samhandling. Det innebærer at helsepersonell må tåle utryggheten som ligger i det å gi noe av kontrollen til pasienten.
Women Who Self-harm Experience Admission Into Acute Mental Health Care as Promoting Recovery.

Background: Self-harm is a frequent reason for admission into acute mental health care despite the fact that guidelines discourage this. There are few descriptions of how admissions could promote the patient's recovery.

Objective: To explore how women with a history of self-harm experience the promotion of recovery during admission in mental health acute wards.

Method: The study applies a phenomenological hermeneutics approach. Five women with a history of self- harm gave descriptions of treatment during interviews and by mail.

Results: Recovery was related to 1) The importance of fellowship, 2) The importance of equality and 3) The importance of responsibility. The description «because there are people there» became the comprehensive understanding of the study. The request for admission was experienced as a strategy to cope. The opportunity to emotionally withdraw was described as essential to recovery. The acute ward represented a social environment that promoted recovery. Available healthcare professionals were considered to be essential for recovery during admission particularly for the acute ward. Healthcare professionals contributed to a feeling of appreciation as well as challenge to take responsibility.

Conclusion: Available healthcare professionals who appreciate the patient's autonomy and participation are vital for the admission to promote recovery. This means that healthcare professionals have to stand the insecurity of transferring some of the control to the patient.

Key words: Qualitative study, mental health, user participation, recovery, institution, woman 


\section{Kvinner som selvskader opplever bedring ved innleggelse i akutt psykisk helsevern}

Forfattere: Jan Hammer, Katrine Wilhelmsen, Monica Strand, Gry Bruland Vråle

\section{NøKKELORD}

- Kvalitativ studie

- Psykisk helse

- Brukermedvirkning

- Rehabilitering

- Kvinne

\section{INTRODUKSJON}

Selvskading beskrives som et lite utforsket område (1). Det er behov for kunnskap fra mennesker som selvskader om hvordan behandling i døgnpost i psykisk helsevern kan støtte deres bedringsprosess $(2,3)$. Forskning om effekt av behandling i døgnpost er sparsom (4). Det er viktig å innhente kunnskap fra personer med egenerfaring om døgninnleggelse i akutt psykisk helsevern, heretter kalt akuttpost (5). Deres erfaringskunnskap må sees som et virkemiddel i kunnskapsutvikling for helsepersonell $(2,3,6)$.

Bedring kan forstås som en prosess (7) hvor personen blant annet gjenoppdager og gjenoppbygger en varig følelse av selvtillit som aktiv og ansvarlig agent (8). Selvskading omfatter selvpåført indre eller ytre skade som overdose eller ved å skjære i kroppen (9). Videre inkluderer det redusert selvivaretakelse som det å ikke reagere på alvorlige kroppslige symptomer (9).

Selvskading forstås hovedsakelig uavhengig av selvmordsintensjon (10-13). Flere studier viser at selvskading forekommer omtrent tre ganger hyppigere hos kvinner enn hos menn $(14,15)$. Samtidig har ideen om selvskading som et problem blant kvinner gjentatte ganger blitt tilbakevist de siste årene $(16,17)$. Retningslinjer anbefaler å behandle både selvskading og mindre alvorlige selvmordsforsøk ambulant (18). Ved nødvendig innleggelse ved akutt selvmordsfare, anbefales innleggelse kun for den akutte selvmordskrisen (18). Selvskading er imidlertid en vanlig årsak til innleggelse (11,18-20). Tilgjengelig litteratur om hva innlagte pasienter som selvskader opplever som bedringsfremmende under innleggelse, handler blant annet om helsepersonells respekt, tilgjengelighet, forståelse og støtte samt eget ansvar for bedringsprosessen og medvirkning i egen behandling (2,3,21-26). Disse studiene omhandler ikke spesifikt døgnopphold i akutt psykisk helsevern.

Hensikten med studien var å utforske hvordan kvinner med egenerfaring med selvskading opplever at bedringsprosessen kan fremmes under innleggelsen i akuttpost. Studien søker å besvare to forskningsspørsmål:

- Hvordan opplever kvinner som selvskader at døgninnleggelser i akutt psykisk helsevern bidrar til bedring?

- Hvilken betydning opplever kvinner som selvskader at helsepersonell har for bedringsprosessen?

\section{Hva tilfører artikkelen?}

Studien viser at kvinner som selvskader kan oppleve bedring ved selvvalgt innleggelse i døgnpost i akutt psykisk helsevern.

\section{Mer om forfatterne:}

Jan Hammer er spesialsykepleier med master i klinisk helsearbeid og arbeider som rådgiver i FoUavdelingen, Klinikk for psykisk helse og rus, VV HF. Katrine Wilhelmsen er spesialsykepleier med master i klinisk helsearbeid og arbeider ved Mottaksseksjonen, Klinikk for psykisk helse og rus, VV HF og som høgskolelektor ved Høgskolen i Buskerud. Monica Strand er sykepleier med videreutdanning i psykisk helse og master i sykepleievitenskap. Hun arbeider med forskning og utviklingsarbeid i Klinikk for psykisk helse og rus, VV HF. Gry Bruland Vråle er psykiatrisk sykepleier og førstelektor ved Diakonhjemmet Høgskole. Kontakt: jan. hammeravestreviken.no. 


\section{METODE}

Kvalitativ forskningsmetode er egnet til å skape kunnskap om et lite studert fenomen (27). Studien har et fenomenologisk-hermeneutisk design. Studien søker etter meningsinnhold i bedringsprosesser ved å beskrive, undersøke og forstå deltakernes erfaringer $(28,29)$.

\section{Utvalg}

Et strategisk utvalg av fem kvinner $\mathrm{i}$ alderen 23-38 år, med selvskadingserfaring opp til 25 år tilbake i tid og fra tjue til to hundre innleggelser på akuttposter i seks ulike fylker i Norge, sendte deltakerne utdyping av temaer på mail til forskerne som er innlemmet i datamaterialet. Fokusgruppeintervjuet varte 90 minutter. Individuelle intervjuer varte cirka 60 minutter.

Vi valgte fokusgruppeintervju for å få innsikt i deltakernes felles erfaringer, behov og ønsker om helseproblemer og helsetjenesten, og for å gjøre bruk av gruppedynamikk $(30,31)$. Som nøytralt intervjusted valgte vi lokale i en interesseorganisasjon (27). Et semistrukturert intervjudesign som reflekterte studiens tema ble utarbeidet i samarbeid med erfaringskonsulenten. Avslutningsvis

\section{Det er liksom hele grunnen til at jeg er innlagt; fordi det er mennesker der.}

deltok i studien. Kontakten med deltakerne ble etablert via en interesseorganisasjon og via en erfaringskonsulent som også hadde en rådgivende rolle i studien.

\section{Etiske overveielser}

Studien ble godkjent av Norsk samfunnsvitenskapelig datatjeneste (prosjektnummer 25574). Informasjon om studien ble gitt ved forespørsel om deltakelse før intervjuene. Informasjon om at deltakerne når som helst og uten konsekvenser kunne trekke seg som deltakere i studien, ble gitt før og etter intervjuene. Deltakernes anonymitet er sikret ved at sitater og beskrivelser ikke kan knyttets til deres kontekst eller person. Intervjuene kunne føre til berøring av sårbare temaer. Deltakerne fikk mulighet til å kontakte en person i interesseorganisasjonen ved behov for henvisning til profesjonell hjelp.

\section{Datainnsamling}

Data ble samlet inn ved ett fokusgruppeintervju og fem individuelle intervjuer. I tillegg ble det foretatt en oppsummering med mulighet for korrigering fra gruppen.

Individuelle intervjuer er formålstjenlig for å fordype seg i sensitive temaer som fordrer trygghet (29). Tema fra fokusgruppeintervju dannet utgangspunkt for de individuelle intervjuene. Ett intervju ble gjennomført ansikt til ansikt og fire per telefon.

\section{Analyse}

Intervjuene ble tatt opp på lydbånd og transkribert. Lindseth og Nordberg (28) har utviklet en fenomenologisk hermeneutisk metode for tekstanalyse hvor utarbeiding av en helhetsforståelse av meningen i datamaterialet er målet. Mening og forståelse skapes i en dialektisk prosess som består av tre steg; naiv lesing av teksten, en strukturell analyse og formulering av en helhetsforståelse.

Etter naiv gjennomlesning av teksten fra fokusgruppeintervjuet utførte vi en usystematisk kategorisering. For eventuelt å finne temaer som ikke sto i temaguiden, fokuserte vi på deltakernes utsagn. Et sammendrag av kategoriseringen ble sendt til deltakerne for gjennomlesing før de individuelle intervjuene. Teksten fra de individuelle intervjuene ble gjennomlest flere ganger. Vi gjorde en strukturell analyse ved at all tekst ble inndelt i meningsbærende enheter $i$ form av setninger og avsnitt innarbeidet $i$ en matrise (subtema og tema). I den strukturelle analysen abstraherte vi til slutt tre temaer. For å komme frem til en helhetlig forståelse, ble all tekst lest gjennom med den naive forstålsen med temaene fra den strukturerte analysen som bakteppe. Forfatternes forforståelse, kritisk refleksjon og dialog med fagpersoner, samt litteratur, har i denne prosessen vært vesentlig.

\section{RESULTATER}

\section{Strukturell analyse}

\section{1) Betydningen av fellesskap}

Et tema deltakerne la vekt på var opplevelsen av kontakt og samhandling med helsepersonell. Deltakerne beskrev en forventning om menneskelig kontakt ved innleggelsen, at helsepersonell bryr seg og er tilgjengelige. «Det er liksom hele grunnen til at jeg er innlagt; fordi det er mennesker der». Deltakerne beskrev hvordan samvær ga opplevelse av å bli verdsatt og av at noen ønsket å tilbringe tid sammen med dem. Det var viktig å ikke føle seg alene: «For meg var det å være på et rom alene, det likner på å være død. ... og så fant de meg og spurte om jeg ville bli med ut, ২i vil ikke at du skal være død, sa de indirekte til meg sånn som jeg forsto det. Vi vil ha deg her sammen med oss i noe sosialt»». Deltakerne beskrev samvær som mer enn fysisk tilstedeværelse. De vektla 
det å holde ut sammen, å være et korrektiv og en utfordrer, samt det å formidle interesse, tid og kjennskap til pasienten, som viktig. Deltakerne la vekt på at samhandling med helsepersonell ga læringsmuligheter ved tilbakemelding og utfordringer i vanskelige situasjoner: "Hvis du løper sammen med meg er det noe helt annet, for da er jegplutselig sammen med et medmenneske som vil bruke tid på at jeg kanskje skal lære meg en teknikk eller kanskje skal holde ut den timen her mens vi løper. Jeg synes det er en himmelforskjell på å være en og å være to».

Deltakerne fortalte at de ikke alltid klarte å fortelle om egne behov eller hva som kunne hjelpe dem. Forslag fra helsepersonell om mestringsstrategier motiverte til utprøving. Deltakerne omtalte det som forsiktig "pushing». Avtaler og skriftlig plan som samarbeidsredskaper, ble vektlagt av deltakerne som praktiske hjelpemidler til å kartlegge hjelpebehov. Deltakerne uttrykte at det var til hjelp når helsepersonell bidro til oppmerksomhet på endring og bedring som hadde skjedd over tid. God relasjon til helsepersonell var viktig for deltakerne og for bedringsprosessen: "At du plutselig må ta hensyn til kontakten din. Det var vel ei som nevnte at nå må du ikke stikke av for jeg orker ikke løpe i dag. Får du god kjemi med noen så vil du automatisk også vise det mennesket respekt».

2) Betydningen av likeverdDeltakerne ga uttrykk for at det er betydningsfullt å bli sett som likeverdig og anerkjent av helsepersonell. De hevdet at en brukerstyrt plass kunne få dem til å føle seg verdsatt og velkommen til posten. «Hvis jeg bare kan komme, så synes jeg at de gir meg en verdi, at jeg er verdi- full nok til å komme og at jeg får det uten å krangle». Deltakerne understreket at de følte seg sett som mennesker når helsepersonellet viste tillit ved for eksempel å delta i praktiske gjøremål. A være tilliten verdig var viktig og kunne bidra til den enkeltes evne og vilje til å ta ansvar og være aktør i egen bedringsprosess. Ikke minst ble følelsen av likeverd styrket hos deltakerne når helsepersonell delte interesser og erfaringer fra eget liv med dem: «Så klart, en skal ikke brette ut om alt mulig, men bare være både et sårbart menneske og et sterkt menneske, fordi det er jo sånn vi er - vise seg som et vanlig menneske».

Når helsepersonell anerkjente og tålte følelsesuttrykk, kunne deltakerne bruke akuttposten som et sted for å bli kjent med egne følelser. Flere deltakere beskrev det «å få lov til å være den lille» som viktig i en bedringsprosess på akuttpost. De skildret det som en tilstand der de i ulik grad ble som barn ved håndtering av følelser. De hevdet det var nødvendig for å lære å bli kjent med egne følelser, og å føle seg trygge slik at de kunne tørre å utfordre seg selv. Deltakerne hevdet at arbeid med følelser bidro til bedring: "Jeg var redd for å ligge i sengen, så jeg spurte ¿Kan vi ikke legge madrassen ned på gulvet?, som et lite barn som på en måte ikke skal falle ut av sengen, og det fikk jeg lov til, ... bare å få lov til og vokse opp litt på følelseslivet».

3) Betydningen av å ta ansvar

Deltakerne beskrev det å være aktive og ta ansvar i behandlingen som viktig for bedringsprosesser. Det fysiske miljøet beskrev deltakerne som en nødvendig sikkerhet for å våge nye utfordringer. Rutinene på akuttposten som faste måltider, gjøre- mål og regler, kunne gi struktur. Slik opplevde deltakerne at de ble holdt fast i virkeligheten gjennom hverdagslivets aktiviteter.

Når deltakerne selv hadde bedt om innleggelse, opplevde de at de hadde tatt ansvar for å søke hjelp i stedet for å overlate det til andre. En deltaker beskrev læringseffekten i et langsiktig perspektiv: «Når jeg da har valgt å legge meg inn, så tok jeg det valget, nå kan jeg ikke selvskade, jeg er nødt å holde ut. Og så lærer en etter hvert at det går over, og så skjer det flere ganger at det går over, og så etter hvert så lærer man å håndtere det òg».

En deltaker sa at det å ha kjente redskaper som hun hadde kontroll over kunne minske sjansen for alvorlig selvskading. Muligheten til å skade seg selv ga minsket stress og økt mot til å holde ut selvskadingstrang: «Jeg kunne klare å holde det ut, fordi at stresset med at noen skulle ta det fra meg ikke var der. Jeg hadde hele tiden den muligheten, sånn som det er hjemme ... ved at jeg hadde lov, så turte jeg å utsette det». Andre deltakere mente at hensikten med innleggelse ikke var å ha mulighet til selvskading, men å ta imot hjelp som også inkluderer inndragning av selvskadingsredskaper. Deltakernes erfaring var at de våget å ta mer ansvar for å bruke andre mestringsstrategier enn selvskading når helsepersonellet var sammen med dem.

Deltakerne beskrev akuttpost som en god treningsarena for utfordring og mestring i den akutte krisen og som forberedelse til livet etter utskrivelse. De beskrev daglige konkrete utfordringer og målsetting som betydningsfulle fordi det kunne gi en følelse av mestring: «Jeg tror det hadde vært så viktig for alle å ha små mål i løpet av dagen. Sånn 
at noen kan si før en legger seg at en har fått til noe».

\section{Helhetsforståelse}

Helhetsforståelse av funnene kan beskrives gjennom informantenes vektlegging av tilgjengelig menneskelig kontakt. Det å ha helsepersonell rundt seg hele døgnet er en avgjørende forskjell fra ambulant behandling, og ble beskrevet som motivasjon for innleggelse. Tilgjengelig helsepersonell skapte forutsigbarhet og ga en nødvendig støtte til å våge å ta utfordringer, seg, blir beskrevet som vanlig praksis $(1,33)$.

\section{Tilgjengelig helsepersonell}

Deltakerne i denne studien poengterer betydningen av å ha helsepersonell tilgjengelig i utfordrende situasjoner og hevder at en trygg relasjon er grunnmuren i bedring ved innleggelse. Deltakerne mener at den trygge relasjonen med helsepersonell var en forutsetning for å våge å ta utfordringer. Ved innleggelse i akuttpost er det tilgjengelig helsepersonell hele døgnet.

\section{Jeg synes det er en himmelforskjell på å være en og å være to.}

samtidig som det ga en opplevelse av å bli verdsatt som menneske. Beskrivelsen «fordi det er mennesker der» er en tolket helhetsforståelse av at samarbeidet mellom pasient og helsepersonell kan forstås som det sentrale i bedringsprosessen ved akuttposten.

\section{DISKUSJON}

\section{Studiens funn}

Deltakerne beskriver ønske om innleggelse ut fra behov for mellommenneskelig kontakt, et nødvendig pusterom og mulighet til utfordring gjennom aktiv samhandling med helsepersonell. Dette beskrives som viktig for å kunne ta fatt på egen bedringsprosess. Deltakerne vurderer anerkjennelse og likeverd som sentralt for sin opplevelse av egen bedringsprosess ved innleggelse. Medbestemmelse ved innleggelse og i behandlingen, bidrar til opplevelse av anerkjennelse. Det kan være en utfordring å imøtekomme dette dersom innleggelse kun tilbys ved akutt selvmordsfare der det primære fokus for helsepersonell vil være sikkerhet og overtakelse av kontroll (32). $\AA$ anse sikkerhet som en prioritet og å unngå at pasienten skader
Pasienter klarer å forholde seg til egen utrygghet når de opplever at helsepersonell er tilgjengelig (34). Det kan imidlertid oppstå problemer om pasientens trygghet i akuttposten ved korte innleggelser er hovedmålet. Å fungere godt på en trygg døgnpost kan være vanskelig å overføre til en utrygg hjemmesituasjon (32). Pasienten kan komme til å søke til akuttposten som det eneste stedet vedkommende opplever trygghet. Dette kan skape et problemforsterkende avhengighetsforhold, hyppige reinnleggelser og vanskeliggjøre utskrivelse $(32,35)$. Bedring er en prosess hvor personen utvikler en bedret og mer stabil selvfølelse (8). Når pasienten legges inn er det hensiktsmessig å benytte relasjonen med helsepersonell som plattform for endringsarbeid (36).

\section{Samhandling}

Deltakerne i studien beskriver medvirkning som godt samspill med helsepersonell og dette opplever de som betydningsfullt. Medvirkning i behandling fører til at pasienten opplever økt kontroll, ansvar, håp og optimisme i forhold til fremtiden (21). Posi- tive aspekter ved innleggelse $\mathrm{i}$ akuttpost kan knyttes til autonomi og kvalitet i menneskelig interaksjon (37). Pasienter føler seg verdifulle ved inkludering og ansvarliggjøring i eget tempo (3). Samhandling mellom helsepersonell og pasient som øker pasientens ferdigheter, oppmuntrer til ansvarsfølelse (38). Deltakerne i studien poengterer at helsepersonell som tok initiativ og hadde en aktiv rolle, hjalp dem til å bryte ut av isolasjon. Om helsepersonellet bruker tid på aktiv samhandling med pasienten, kan det redusere tiden de bruker på negativ atferd og krisetilstander (39).

\section{Et nødvendig pusterom}

Deltakerne beskriver akuttposten som et sted der de kunne være den lille, og slik lære å kjenne egne følelser. Dette kan forstås som en nødvendig pause i hverdagen og som læringsmulighet. Tilbaketrekning kan gi mulighet til indre prosesser som kan hjelpe personen til å orientere seg, og være grunnleggende for pasientens vekst (40). Midlertidig hvile fra virkelighetens krav kan være nødvendig for å forhindre forverring (41). Utfordringen kan være at det å være den lille og den midlertidige hvilen kan bli en vedvarende eller hyppig tilbakevendende tilstand. Begrunnelsen for å begrense innleggelser er nettopp faren for problemforsterkende prosesser (35). At både helsepersonell og pasient har fokus på så vel helsefremmende som problemforsterkende handlinger, kan etter vår vurdering bidra til nyansert hjelp til de som trenger innleggelser. Dette kan tematiseres i samtaler med pasienter slik at man finner fram til felles holdning og mål.

\section{Ansvarliggjøring}

Brukerne hevder at ansvarlig 
og aktiv deltakelse i behandling inkluderer muligheten til regulering av selvskading $(2,21,42)$. En deltaker hevdet at hun reduserte selvskadingen når hun selv hadde ansvar for den. En deltaker nevnte at selvskading hindret henne i å begå selvmord, en erfaring som også beskrives i litteraturen $(13,26,43,44)$. Når helsevesenets forventning er å kontrollere selvskade, kan man hindre pasientens autonomi. Samtidig kan det være nødvendig å regulere pasientens selvskading. Reguleringen må da være forankret i en empatisk holdning og ikke gi respons som i neste omgang kan øke selvskading $(34,36,45)$.

Helsepolitiske føringer som hevder at innleggelse av personer som selvskader er uheldig, kan føre til at pasientens ønske om innleggelse blir en maktkamp (12). Pasienten kan da oppleve ignorering fra helsepersonell. Det kan paradoksalt nok forverre pasientens symptomer (33). Deltakerne beskriver ønske om innleggelse som å velge bort å skade seg. En bønn om hjelp kan være tegn på bedring ved at man tar ansvar for egen situasjon (40). Erfaringer med brukerstyrte plasser hvor pasienten selv tar ansvar for å be om innleggelse, viser at antall liggedøgn totalt kan gå ned $(46,47)$. Dette kan tyde på at balanse mellom anerkjennelse av brukerens behov og ansvarliggjøring kan bidra til mestring av egen situasjon.

\section{Metodekritikk}

Til nå er det sparsomt med studier som fokuserer på behandling av personer som selvskader, dette gir studien relevans (1-3). Kvalitative forskningsintervjuer egner seg for få fram intervjupersonens erfaringer og dialogen om felles erfaringer kan romme tabubelagte områder (48). Studiens gyldighet kan derfor begrunnes ut fra deltakernes erfaringskunnskap om temaet. Vi har søkt å ivareta refleksiviteten ved å inkludere erfaringskonsulent, ha dialog $\mathrm{i}$ intervjuer, samt diskutere studiens resultater de fire forfatterne imellom. Vi har tilstrebet å tydeliggjøre forskerprosessen slik at

\section{Får du god kjemi med noen så vil du auto- matisk også vise det mennesket respekt.}

andre kan bedømme kvaliteten på arbeidet (49). Kombinasjonen av fokusgruppeintervjuer og individuelle intervjuer, som en triangulering, kan øke reliabiliteten i data (49). Fem deltakere som ble intervjuet to ganger, er likevel ikke nok til å få frem alle variasjoner ved bedringsprosessene i denne konteksten. I litteratur og tidligere studier framkommer liknende fenomener som i våre funn $(3,21-23)$ Dette kan tyde på at resultatene kan ha noe overføringsverdi. Overføringsverdien til kvinner under 20 år og over 40 år og til menn er usikker, siden kun kvinner mellom 23-38 år deltok. Slik har det stort sett også vært i liknende studier $(2,3,23,24,26)$.

\section{KONKLUSJON}

Deltakerne i studien hevdet, i motsetning til helsepolitiske føringer om å unngå innleggelser, at det å bli møtt på ønske om innleggelse og å få være den lille, fremmet bedringsprosessen. Deltakerne hadde ikke primært fokus på beskyttelse, slik helsepersonell har det. Deltakerne vektla betydningen av tilgjengelig helsepersonell som særegent ved akuttposten og som grunn for at døgninnleggelse ga bedring. Helsepersonell hadde betydning både for at deltakerne følte seg verdsatt og for å bli utfordret til ansvarliggjøring. Helsepersonell bør derfor tåle utryggheten som ligger i det å gi pasienten kontroll. Deltakernes erfaringskunnskap bør vurderes på like fot med helsepersonells kunnskaper og tjene som veiviser i pasientnære situasjoner med personer som selvskader. Siden brukerkunnskap om dette temaet er sparsom,

anbefales det å gjennomføre lignende studier, der også menn og kvinner i andre aldre inkluderes som deltakere. Det er behov for kunnskap om medvirkning og terapeutiske og samhandlende intervensjoner som fremmer bedring.

\section{REFERANSER}

1. O'Donovan À, Gijbels H. Understanding psychiatric nursing care with nonsuicidal self-harming patients in acute psychiatric admission units: the view of psychiatric nurses. Archives of Psychiatric Nursing 2006;20:186-92.

2. Duperouzel H, Fish R. Why couldn 't I stop her? Self injury: the views of staff and clients in a medium secure unit. British Journal of Learning Disabilities 2007:36:59-65.

3. Lindgren B-M, Wilstrand C, Gilje F, Olofsson B. Struggling for hopefulness: a qualitative study of Swedish women who self-harm. Journal of Psychiatric and Mental Health Nursing 2004;11:284-91.

4. Bowers L, Chaplin R, Quirk A, Lelliott

P. A conceptual model of the aims and functions of acute inpatient psychiatry. Journal of Mental Health 2009:18:316-25. 5. Quirk A, Lelliott P. What do we know about life on acute psychiatric wards in the UK? A review of the research evidence. Social Science \& Medicine 2001; 53:1565-74

6. Bywaters P, Rolfe A. Looking beyond the scars. Understanding and responding to self injury and self harm. NCH, London. 2002.

7. Topor A. Hva hjelper? Veier til bedring fra alvorlige psykiske problemer. Kommuneforlaget, Oslo. 2006.

8. Davidson L, Strauss JS. Sense of self in recovery from severe mental illness. British Journal of Medical Psychology 1992;65:131-145. 
9. Turp M. Skin toughening and skin porosity: addressing the issue of self-harm by omission. I: Briggs S., Lemma A., Crouch W. (red.). Relating to self-harm og suicide - Psychoanalytic perspectives on practice, theory and prevention. Routledge, East Sussex. 2008 (s.198-209).

10. Favazza A. Bodies under Siege: Self-mutilation and body modification in culture and psychiatry (2. edt.). John Hopkins University Press, Baltimore. 1996.

11. McAllister M. Multiple meanings of self harm: A critical review. International Journal of Mental Health Nursing 2003;12:177-85.

12. Paris J. Kronisk suicidalitet ved ustabil personlighetsforstyrrelse. Hvorfor det er behov for særskilte tilnærminger i behandlingen. Suicidologi 2010;15:3-7. 13. Bloch Thorsen GR. Selvskading og selvmord ... ingen selvfølge. Suicidologi 2006;11:5-9.

14. Claes L, Vandereycken W, Vertommen $\mathrm{H}$. Self-injury in female versus male psychiatric patients: A comparison of characteristics, psychopathology and aggression regulation. Personality and Individual Differences 2006; 42: 611-21. 15. Ystgaard M. Villet egenskade blant ungdom: nye forskningsresultater og konsekvenser for forebyggende arbeid. Suicidologi 2003;8:7-10.

16. O'Loughlin S, Sherwood L. A 20-year review of trends in deliberate self-harm in a British town, 1981-2000. Social Psychiatry and Psychiatric Epidemiology 2005; 40:446-53.

17. Warm A, Murray C, Fox J. Why do people self-harm? Psychology, Health \& Medicine 2003;8:71-79.

18. Sosial- og Helsedirektoratet. Nasjonale retningslinjer for forebygging av selvmord i psykisk helsevern. IS-1511. 2008.

19. Bowers L. Reasons for admission and their implications for the nature of acute inpatient psychiatric nursing. Journal of Psychiatric and Mental Health Nursing 2005;12:231-6.

20. Claasen CA, Trivedi, M.H., Shimizu, I., Stewart, S., Larkin, G.L., og Litovitz, T. Epidemiology of nonfatal deliberate self-harm in the United States as described in three medical databases. Suicide and Life-Threatening Behavior 2006;36:192-212.

21. Bosman M, van Meijel B. Perspectives of Mental Health Professionals and
Patients on Self-Injury in Psychiatry: A Literature Review. Archives of Psychiatric Nursing 2008;22:180-9.

22. Kool, N., van Meijel B. \& Bosman M. Behavioral Change in Patients With Severe Self-Injurious Behavior: A Patient's Perspective. Archives of Psychiatric Nursing 2008; 23:25-31.

23. Palmer L, Blackwell, H., og Strevens, $P$. Service users' experience of emergency services following self-harm - A national survey of 509 patients. The Royal College of Psychiatrists - Better Services for People who Self-Harm. 2007.

24. Rovik, A.M. Selvskading og miljøterapi - Selvskadende pasienters erfaringer med å være innlagt i psykiatriske avdelinger. Nordisk Sygeplejeforskning 2011; 4: 299-313.

25. Smith SE. Perceptions of service provision for clients who self-injure in the absence of expressed suicidal intent. Journal of Psychiatric and Mental Health Nursing 2002;9:595-601.

26. Weber MT. Triggers for self-abuse: A qualitative study. Archives of Psychiatric Nursing 2002; 16:118-24.

27. Polit DF, Beck CT. Nursing research - Generating and Assessing Evidence for Nursing Practice. 8. edt. Lippincott Williams \& Wilkins, Philadelphia. 2008. 28. Lindseth A, Norberg A. A phenomenological hermeneutical method for researching lived experience. Scandinavian Journal of Caring Sciences 2004:18:145-53.

29. Malterud K. Kvalitative metoder medisinsk forskning. 2. Utgave, 4. opplag Universitetsforlaget, Oslo. 2008.

30. Lerdal A, Karlsson B. Bruk av fokusgruppeintervju. Sykepleien Forskning. 2008; 3: 172-5.

31. Stewart DW, Rook DW, Shamdasani PN. Focus Groups: Theory and Practice. 2. rev. edt. London: Sage Publications Ltd. 2006.

32. Stangeland T. Når sikreste behandling ikke er beste behandling. Tidsskrift for Norsk Psykologforening 2012;49:13844.

33. Edwards SD, Hewitt J. Can supervising self-harm be part of ethical nursing practice? Nursing Ethics. 2011;18:79-87. 34. Crittenden PM. Raising parents: attachment, parenting and child safety. Willan Publishing, Cullompton. 2008.

35. Paris J. Is hospitalization useful for suicidal patients with borderline personality disorder? J Pers Disord.
2004:18:240-7.

36. Swenson CR, Sandersen C., Dulit $\mathrm{R}$, Linehand M. The application of dialectical behavior therapy for patients with borderline personality disorder on inpatient units. Psychiatric Quarterly 2001:72:307-24.

37. Walsh J, Boyle J. Improving Acute Psychiatric Hospital Services According to Inpatient Experiences. A UserLed Piece of Research as a Means to Empowerment. Issues in Mental Health Nursing 2009;30:31-8.

38. Mullen, A. Mental health nurses establishing psychosocial interventions within acute inpatient settings. International Journal of Mental Health Nursing 2009:18:83-90.

39. Baker J. Developing psychosocial care for acute psychiatric wards. Journal of Psychiatric and Mental Health Nursing 2000;7:95-100.

40. Borg M, Topor A. Virksomme relasjoner: Om bedringsprosesser ved alvorlige psykiske lidelser. Kommuneforlaget, Oslo. 2007.

41. Cullberg J. Dynamisk psykiatri i teori og praksis (5. utg.). Tano Aschehoug AS, Oslo. 1998

42. Klonsky ED, Muehlenkamp JJ. SelfInjury: A Research Review for the Practitioner. Journal of Clinical Psychology 2007;63:1045-56.

43. Nock MK, Cha CB. Psychological models of nonsuicidal self-injury. I: Nock M.K. (red.). Understanding Nonsuicidal Self-Injury. American Psychological Association, Washington: 2009 (s 65-77). 44. Urnes $\emptyset$. Selvskading og personlighetsforstyrrelser. Tidsskrift for Den norske legeforening 2009:129:872-6.

45. Hammer J \& Heggdal D. Vil BET bidra til mer effektiv behandling? SykepleienPsykisk Helse og Rus 2011;3:12-17.

46. Anda SO. Åpen innleggelse gav bedre Liv. Tidsskrift for Norsk Psykologforening 2010;47:35-7.

47. Nome HH, Skinnerlien TE. Virksomhetsrapport om 3-dagersavtalen ved SSHF akuttpsykiatrisk post 6.1. Kristiansand. (Upublisert materiale). Sørlandet Sykehus HF, Kristiansand. 2010.

48. Kvale S, Brinkmann S. Interview introduktion til et håndværk. 2. utgave. Hans Reitzels Forlag, København. 2009. 49. Halkier B. Fokusgrupper. Gyldendal Norsk Forlag, Oslo. 2010. 